\title{
Momentum for Independent versus Group Firms
}

\author{
Hsiao-Peng $\mathrm{Fu}^{1}$ \\ ${ }^{1}$ Department of Finance, Providence University, Taiwan, R.O.C. \\ Correspondence: Hsiao-Peng Fu, Department of Finance, Providence University, 200, Section 7, Taiwan Boulevard \\ Road, Shalu District, Taichung 43301, Taiwan, R.O.C. Tel: 8864-2632-8001 Ext. 13614.
}

\author{
Received: March 2, 2016 \\ Accepted: March 15, 2016 \\ Online Published: June 25, 2016 \\ doi:10.5430/ijfr.v7n4p14 \\ URL: http://dx.doi.org/10.5430/ijfr.v7n4p14
}

\begin{abstract}
A prior research finds a significant seasonal momentum in the Taiwanese stock market. While intending to explore rationales for the seasonal momentum, this study use a relatively large dataset to verify whether strength of the momentum is different across independent and group firms. Empirical evidence do not report significant differential momentum effect between the two types of firms, inconsistent with prior findings, which reveal more pronounced momentum on independent firms.
\end{abstract}

Keywords: price momentum, seasonality, emerging markets, group firms

\section{Introduction}

One feature of Asian firms is domination of group firms, i.e., firms closely associated with other firms in terms of cross holding of shares or common controlling under a person, a family, or a group of related families (Claessens $e t$ al., 2000). Chui et al. (2003) examine relation between price momentum and independent/group firms, finding stronger momentum among independent firms than among group firms. In this study, we duplicate their tests in a much larger dataset composed of both listed and delisted Taiwaneses firms.

Basically, there are two competing theories explain why the strength of momentum will be different between independent and group firms. At one hand, the psychological bias theory asserts that group firms' financial statements are more complex and less transparent than those of independent companies owing to the complexity of cross holding of shares and exchanging of resources among affiliated firms (Khanna and Palepu, 2000; Khanna, Palepu, and Srinivasan, 2004). As a result, momentum profits for group firms are higher due to higher sophistication and opacity in information, which is more likely to triggers psychological biases, such as overconfidence and self-attribution suggested by Daniel, Hirshleifer and Subrahmanyam (1998). They argue that those biases are underlying drives of momentum effects. On the other hand, the stabilisation theory suggests that group firms exhibit less momentum effects due to strong motivation to stabilise stock prices of the affiliated firms, or having more stabilisation tools such as using business relationship within the groups (Chui et al., 2003). Consequently, independent firms are more likely to produce higher momentum effects resulted from less stabilisation trading. Accordingly, comparing momentum performance between the two kinds of firms throws light on identifying the underlying source of momentum effects.

I use a sample approximately 1.5 times of the number of firms used by Chui et al. The null hypothesis is that there is no significant momentum differential between group and independent firms. The stabilisation (psychological bias) theory will be accepted in the presence of significant larger momentum profits among independent (group) firms.

Consistent with $\mathrm{Fu}$ and Wood (2010), this study finds strong Taiwanese momentum during April to Auguest. Strength of the momentum, however, does not show significant difference between independent and group firms. The lack of discrepancy is inconsistent with either of the two above hypotheses, nor with the strong Taiwanese evidence reported by Chui et al. (2003). This research contributes to momentum literature by sheding further light to findings by Chui et al (2003).

The rest of this paper is structured as follows. The following section present data and methodology. Section 4 reports empirical results, and section 5 concludes. 


\section{Data and Methodology}

I use the annual published survey of 'Business Groups in Taiwan' compiled by China Credit Information Service from 1988 to 2004, identifying 305 group firms in the sample of 675 firms with the remaining as independent firms. For a firm to be eligible as a group firm by the 'Business Groups in Taiwan', all the following criteria have to be fulfilled:

(1) There are three or more firms in the group.

(2) The parent firm(s) is (are) locally registered and more than $51 \%$ of the ownership is held by private firms.

(3) At least one of the following mechanisms is used to construct the affiliation:

(a) In the case of investing subsidiaries through (parent) corporations, rather than through individuals, subsidiaries should be held at least by $50 \%$ ownerships, or mutually be held by at least $33 \%$, or be held with the parent(s) as the largest owner(s).

(b) More than half of the ownership of both the parent(s) and the subsidiaries is held by the same equity-holder(s).

(c) More than half of the directors, monitors, executive stockholders, stockholders are representing the investing firms, and the general manager of the parent(s) is the person who also is the general manager of the subsidiaries.

(d) More than half of the directors, monitors, executive stockholders, stockholders are representing the investing firm, and the general manager of the parent(s) and that of the subsidiaries have relationships in forms of spouse, father (or mother) versus sons (or daughters), or grandfather (or grandmother) versus grandsons (or granddaughters).

(e) Both the parent(s) and the subsidiaries are controlled by the same supervisory organisation.

Following the methodology in Chui et al. (2003) for Asian markets, the loser (bottom 30\%), medium (middle 40\%), and winner (top 30\%) portfolios are ranked on the past J-month returns and are held for the next $\mathrm{K}$ months. The sample is from July 1975 to December 2003. Momentum portfolio return is equally-weighted.

\section{Empirical Results}

\subsection{Momentum Returns by Independent vs. Group Firms}

Table 1 documents a couple of interesting resultings. Firstly, either among independent or group firms, a significant momentum over the April-Auguest period is apparently detected. Secondly, differential momentum returns between the two groups of stocks are too weak to decide which of the two hypotheses is more compelling than the other. The $F$ statistics is also not large enough to refute the hypothesis of no apparently difference of momentum profits across calendar months. The ambiguous evidence is not consistent with strong evidence reported by Chui et al. (2003). 
Table 1. Profitability of momentum strategies for independent vs. group firms $(\mathrm{J}=\mathrm{K}=6)$

\begin{tabular}{lcccccc}
\hline & \multicolumn{2}{c}{ Independent } & \multicolumn{2}{c}{ Group } & \multicolumn{2}{c}{$\mathrm{I}-\mathrm{G}$} \\
\hline & Return & t-stat & Return & t-stat & Return & t-stat \\
\hline All Months & 0.17 & 0.52 & 0.01 & 0.03 & 0.17 & 0.58 \\
\hline Mar-Dec & 0.79 & 2.31 & 0.47 & 1.93 & 0.32 & 1.01 \\
\hline Others (Jan-Feb) & -2.90 & -3.07 & -2.32 & -3.05 & -0.58 & -0.78 \\
\hline Apr-Aug & 1.68 & 3.29 & 1.25 & 4.41 & 0.43 & 0.88 \\
\hline Others (Sep-Mar) & -0.89 & -2.13 & -0.87 & -2.46 & -0.02 & -0.06 \\
\hline January & -3.54 & -2.20 & -3.01 & -2.50 & -0.53 & -0.46 \\
\hline February & -2.24 & -2.30 & -1.60 & -1.74 & -0.64 & -0.68 \\
\hline March & 0.03 & 0.03 & -0.43 & -0.51 & 0.46 & 0.52 \\
\hline April & 0.88 & 0.82 & 0.75 & 1.19 & 0.12 & 0.12 \\
\hline May & 2.47 & 2.40 & 1.53 & 2.62 & 0.94 & 0.95 \\
\hline June & 1.66 & 2.11 & 1.79 & 2.69 & -0.13 & -0.18 \\
\hline July & 2.53 & 1.45 & 1.22 & 2.04 & 1.30 & 0.79 \\
\hline August & 0.88 & 1.04 & 0.96 & 1.35 & -0.08 & -0.10 \\
\hline September & -0.02 & -0.02 & -1.50 & -1.92 & 1.48 & 2.19 \\
\hline October & 0.48 & 0.64 & 0.07 & 0.08 & 0.41 & 0.50 \\
\hline November & -0.57 & -0.56 & 0.75 & 0.70 & -1.32 & -1.38 \\
\hline December & -0.42 & -0.37 & -0.39 & -0.52 & -0.03 & -0.03 \\
\hline F stat & & & & & 0.667 & $(0.770)$ \\
\hline
\end{tabular}

The $t$ statistics are in parentheses.

\subsection{Other Combination of Formation $(J) \&$ Holding $(K)$ Periods}

Table 2 in below reveals a consistency of no evident difference of performance of momentum strategies across independent and group firms, for the situations with ranking/holding periods of 9 and 12 months, respectively.

Table 2. Profitability of momentum strategeies for independent vs. group firms $(\mathrm{J}=\mathrm{K}=9$ or 12$)$

\begin{tabular}{|c|c|c|c|c|c|c|c|c|c|c|}
\hline & \multicolumn{6}{|c|}{$\mathrm{J}=\mathrm{K}=9$} & \multicolumn{4}{|c|}{$\mathrm{J}=\mathrm{K}=12$} \\
\hline & \multicolumn{2}{|c|}{ Independent } & \multicolumn{2}{|c|}{ Group } & \multicolumn{2}{|c|}{$I-G$} & \multicolumn{2}{|c|}{ Independent } & Group & $\mathrm{I}-\mathrm{G}$ \\
\hline & Ret & t-stat & Ret & t-stat & Ret & t-stat & Ret & t-stat & Ret $\mathrm{t}$-stat Ret & t-stat \\
\hline All Months & -0.06 & -0.18 & 0.15 & 0.60 & -0.20 & -0.75 & -0.26 & -0.80 & $-0.15-0.57-0.12$ & -0.44 \\
\hline Mar-Dec & 0.43 & 1.30 & 0.51 & 2.09 & -0.08 & -0.29 & 0.32 & 0.96 & $\begin{array}{lll}0.25 & 0.96 & 0.06 \\
\end{array}$ & 0.23 \\
\hline Others (Jan-Feb) & -2.44 & -2.59 & -1.64 & -2.26 & -0.80 & -0.96 & -3.18 & -3.13 & $-2.15-3.07-1.02$ & -1.25 \\
\hline Apr-Aug & 0.97 & 1.95 & 1.39 & 4.44 & -0.42 & -1.02 & 0.73 & 1.66 & $1.12 \quad 3.38-0.40$ & -1.07 \\
\hline Others (Sep-Mar) & -0.79 & -1.89 & -0.74 & -2.24 & -0.05 & -0.13 & -0.96 & -2.06 & $-1.04-2.96 \quad 0.08$ & 0.22 \\
\hline January & -2.76 & -1.78 & -2.13 & -1.97 & -0.63 & -0.49 & -3.79 & -2.26 & $-2.92-2.89-0.87$ & -0.65 \\
\hline Febr & -2.11 & -1.94 & -1.13 & 6 & -0.98 & -0.90 & -2.54 & -2.2 & $-1.36-1.40-1.18$ & -1.24 \\
\hline March & -0.02 & -0.02 & -0.28 & -0.32 & 0.26 & 0.28 & -0.51 & -0.42 & $\begin{array}{lll}-1.05 & -0.91 & 0.54\end{array}$ & 0.53 \\
\hline April & -0.29 & -0.28 & 0.68 & 1.02 & -0.97 & -0.99 & -0.62 & -0.66 & $\begin{array}{lll}0.05 & 0.07 & -0.67\end{array}$ & -0.76 \\
\hline May & 1.95 & 1.85 & 1.69 & 2.64 & 0.26 & 0.34 & 2.02 & 2.52 & $\begin{array}{lll}1.33 & 2.03 & 0.69 \\
\end{array}$ & 1.20 \\
\hline June & 1.39 & 1.50 & 1.36 & 1.89 & 0.03 & 0.04 & 0.77 & 0.79 & $0.93 \quad 1.36-0.16$ & -0.20 \\
\hline July & 2.52 & 1.87 & 2.48 & 3.31 & 0.04 & 0.04 & 1.61 & 1.47 & $2.37 \quad 2.73-0.75$ & -0.90 \\
\hline August & -0.71 & -0.65 & 0.75 & 1.04 & -1.47 & -1.49 & -0.15 & -0.14 & $\begin{array}{lll}0.89 & 1.19 & -1.03 \\
\end{array}$ & -1.07 \\
\hline September & -0.84 & -0.90 & -1.43 & -1.75 & 0.59 & 0.73 & -0.89 & -0.75 & $-2.15-2.26 \quad 1.26$ & 1.27 \\
\hline October & 0.84 & 1.28 & -0.21 & -0.26 & 1.05 & 1.74 & 0.93 & 1.20 & $\begin{array}{lll}-0.25 & -0.33 & 1.19\end{array}$ & 1.89 \\
\hline November & 0.25 & 0.29 & 0.97 & 1.27 & -0.73 & -1.00 & 0.77 & 0.73 & $1.22 \quad 1.86-0.45$ & -0.54 \\
\hline December & -0.81 & -0.69 & -0.93 & -1.32 & 0.12 & 0.13 & -0.74 & -0.59 & $-0.79-0.98 \quad 0.04$ & 0.05 \\
\hline F stat & & & & & 0.63 & $(0.805)$ & & & 0.88 & $(0.562)$ \\
\hline
\end{tabular}

The $t$ statistics are in parentheses. 


\subsection{Subperiod Analysis}

The subperiod analysis shown in Table 3 still do not report significant differential momentum effect between the two types of firms, consistent with findings in previous tables.

Table 3. Profitability of momentum strategeies for independent vs. group firms by subperiod $(\mathrm{J}=\mathrm{K}=6)$

\begin{tabular}{|c|c|c|c|c|c|c|c|c|c|c|c|c|c|c|c|}
\hline & \multicolumn{5}{|c|}{ Panel A: July 1975 - May 1987} & \multicolumn{4}{|c|}{ Panel B: June 1987 - June 1997} & \multicolumn{6}{|c|}{ Panel C: July 1997 - December 2003} \\
\hline & \multicolumn{2}{|c|}{ Independent } & \multirow{2}{*}{\multicolumn{2}{|c|}{$\frac{\text { Group }}{\text { Ret t-stat }}$}} & \multirow{2}{*}{$\frac{I-G}{\text { et } t \text {-stat }}$} & \multicolumn{2}{|c|}{ Independent } & \multirow{2}{*}{$\frac{\text { Group }}{\text { Ret t-stat }}$} & \multirow{2}{*}{$\frac{I-G}{\text { t Ret t-stat }}$} & \multicolumn{2}{|c|}{ Independent } & \multicolumn{2}{|c|}{ Group } & \multicolumn{2}{|c|}{$I-G$} \\
\hline & Ret & t-stat & & & & Ret & t-stat & & & Ret & t-stat & Ret & t-st & Ret & t-stat \\
\hline & 0.22 & 0.39 & 0.41 & 1.54 & $-0.19-0.56$ & 0.46 & 1.07 & $-0.52-1.3$ & 0.983 .79 & -0.45 & -0.55 & 0.15 & 0.19 & -0.60 & -1.36 \\
\hline pary & -3.27 & -1.54 & $-155-$ & $-18 t$ & $-172-108$ & -0.46 & -0.29 & $-247-1$ & 2.012 .78 & -9.17 & -1.77 & -6.59 & -1.40 & -2.58 & -2.51 \\
\hline & -1.97 & -1.16 & $-252-$ & $1-18+2$ & $\begin{array}{lll}0.54 & 0.59\end{array}$ & -2.36 & -1.63 & $-145-0$ & $-0.91-1.02$ & -2.57 & -1.11 & 0.11 & 0.05 & -2.68 & -1.07 \\
\hline & & 0.42 & 0.73 & 092 & $-0.22-0.23$ & 1.14 & 0.70 & $\begin{array}{lll}0.09 & 0.07\end{array}$ & $1.06 \quad 1.14$ & -3.24 & -0.75 & -4.02 & & 078 & 0.47 \\
\hline & & 0.52 & & & & 0.54 & 0.51 & $-1.02-1$ & 1.562 .04 & & 0.38 & & & & 0.10 \\
\hline & & .97 & & 3.18 & 1.702 .45 & 0.15 & 0.07 & & -0.13 & & 2.54 & & & & 2.10 \\
\hline & & 2.96 & 2.07 & 2.79 & $\begin{array}{ll}0.83 & 0.88\end{array}$ & 0.90 & 0.60 & 1.351. & $-0.45-0.67$ & & 0.61 & 2.21 & & -1.35 & -1.60 \\
\hline & 43 & 0.61 & 0.75 & 0.95 & $\begin{array}{ll}1.67 & 0.67\end{array}$ & 2.80 & 1.37 & 0.700. & 2.092 .28 & 2.26 & 2.20 & 2.96 & & -0.69 & -1.36 \\
\hline 90 & -0.44 & -0.33 & 0.30 & 0.41 & $-0.73-1.02$ & 1.92 & 1.16 & 0.740 .65 & 1.181 .14 & 1.55 & 1.44 & 2.53 & 1.10 & -0.98 & -0.75 \\
\hline$n t a n$ & 1.98 & 1.20 & 0.73 & 0.75 & 1.251 .60 & -0.88 & -0.95 & $-2.62-2.18$ & 1.743 .00 & -2.23 & -1.63 & -3.71 & -2.05 & 1.48 & 0.94 \\
\hline nteror & 0.07 & 0.06 & $-0.66-$ & -083 & $0.73 \quad 1.14$ & 0.74 & 0.66 & 1.370 .91 & $-0.63-0.56$ & 0.79 & 0.39 & -0.79 & -0.30 & 1.58 & 1.25 \\
\hline & -1.94 & -1.34 & 0.90 & 1.01 & $-2.84-3.22$ & 0.33 & 0.19 & $-1.69-0.80$ & 2.012 .35 & 0.45 & 0.18 & 4.53 & 1.99 & -4.08 & -2.64 \\
\hline ecember & -2.12 & -0.91 & 0.09 & 0.09 & $-2.20-2.21$ & 0.69 & 0.86 & $-1.73-2.17$ & 2.413 .41 & 0.87 & 0.35 & 0.98 & 0.39 & -0.11 & -0.07 \\
\hline
\end{tabular}

The $t$ statistics are in parentheses.

\section{Conclusions}

Consistent with Fu and Wood (2010), this study finds strong Taiwanese momentum during April to Auguest. Strength of the momentum, however, does not show significant difference between independent and group firms. The lack of discrepancy is inconsistent with either of the the psychological bias or stabilisation hypotheses mentioned previously, nor with the strong Taiwanese evidence reported by Chui et al. (2003). The results are bound by the research restriction of sample years. Research of more recent years warrants future research.

\section{References}

Chui, A., Titman, S., \& Wei, J. (2003). Momentum, legal systems and ownership structure: an analysis of Asian stock markets. Unpublished working paper. University of Texas at Austin.

Claessens, S., Djankov, S., \& Lang, L. H. P. (2000). The separation of ownership and control in East Asian Corporations. Journal of Financial Economics, 58, 81-112. http://dx.doi.org/10.1016/S0304-405X(00)00067-2

Daniel, K., Hirshleifer, D., \& Subrahmanyam, A. (1998). Investor psychology and security market under-and overreactions. Journal of Finance, 53, 1839-1886. http://dx.doi.org/10.1111/0022-1082.00077

$\mathrm{Fu}$, Hsiao-Peng, \& Andrew, W. (2010). Momentum Profits in Taiwan: Seasonality Matters! Applied Economics Letters, 17, 1247-1253. http://dx.doi.org/10.1080/00036840902917589

Khanna, T., \& Palepu, K. (2000). Is group affiliation profitable in emerging markets? An analysis of diversified Indian business groups. Journal of Finance, 55, 867-891. http://dox.doi.org/10.1111/0022-1082.00229

Khanna, T., Palepu, K., \& Srinivasan, S. (2004). Disclosure practices of foreign companies interacting with U.S. markets. Journal of Accounting and Research, 42, 475-508. http://dx.doi.org/10.1111/j.1475-679X.2004.00146.x 